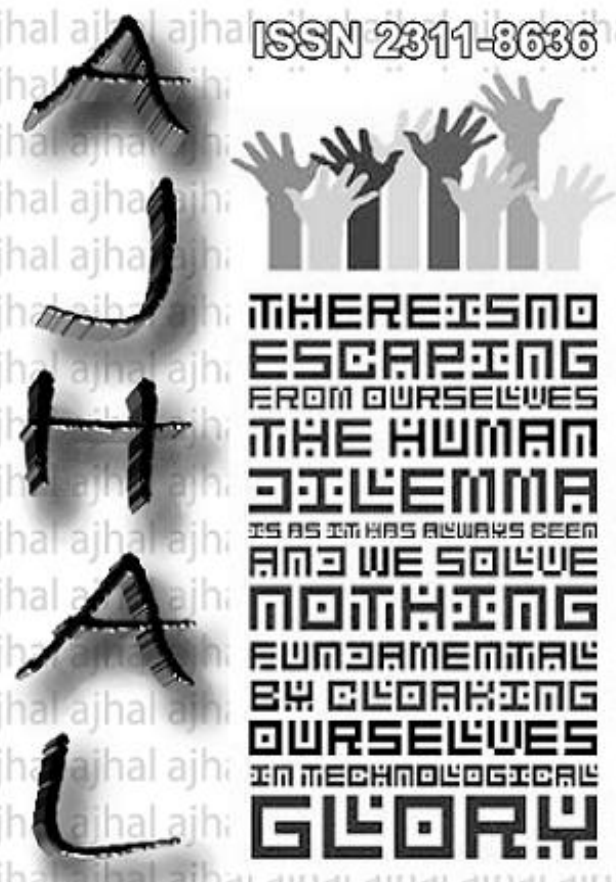

Asian Journal of Humanity, Art and Liteigatul|"

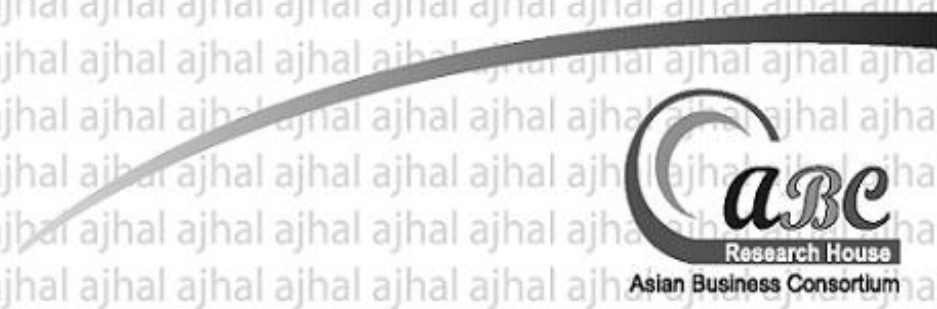




\title{
Kashmir Conflict: Tracing the History Suggesting the Solution
}

\section{Peer Ghulam Nabi, \& Muhammad Ammad Khan}

Department of Development Studies, College of Humanities and Development (COHD), China Agricultural University (CAU), Beijing, China

\begin{abstract}
Kashmir, once known for its mesmerizing beauty, peace and tolerance in the world, has now been seen as a bloody conflict zone, since 1989. Over the years, numbers of Confidence Building Measures (CBMs) were taken by India and Pakistan, but all the initiatives fail to bring long-term peace in the region. This paper examines two questions: why Kashmiris chose to go for armed struggle against India and why peace building initiatives lead by India and Pakistan failed to bring long term peace in the region? The study will further try to analyze the interests of the different stakeholders in order to find a peaceful, acceptable, and achievable solution to the conflict region. On the basis of Stakeholder Analysis the paper argues that India and Pakistan need to go beyond existing nonengagement and occasional bilateral policy of negotiation to trilateral negotiation by engaging Kashmiri political leadership to get the win-win, peaceful resolution of the conflict. The absence of Kashmiris in any negotiation process will not bring long lasting solution to the region.
\end{abstract}

Keywords: Kashmir conflict, India, Pakistan, Insurgency, Peace process JEL Classification Code: R5

\section{INTRODUCTION}

Conflicts whether for a smaller or a bigger cause, whether it aims to serve economic or political interest, before they could achieve their goal, they disrupt the normal way of life. Every conflict is unique in nature. Ethnicity, economic deprivation, urge for independence, fear of cultural assimilation etc. are some of the reasons which create conflict in the society. There are around 140 self-determination movements going on still in the world. All these conflicts have caused huge human and economic loss in the conflict hit regions. For example,in the Israel-Palestine conflict, approximately 1.5 million Palestinian civilians have died since 1948;2 million people have been killed in Sudan; 250,000 Bosnian civilians were killed and 1 million displaced by Serbia against the Bosnia's declaration of independence (Ilan, 2003; Lone, 2006). Thus Conflict not only cost the human lives but also paralyze the basic structure of society; like economy,education, health, besides invisible factors social behavior, social relations and social values of the area.

The Jammu and Kashmir (hereafter Kashmir) which was once known for its mesmerizing beauty, peace and tolerance in the world, has now been discussed as a bloody conflict zone, since 1989; when the peaceful movement of resistance against India took ugly turn. 
The State of Jammu and Kashmiris popularly known as Kashmir and was a separate landlocked country, though not controlled by one ruler. The region was annexed with Jammu district which was already control by Maharaja Gulab Singh, whom British sold Kashmir; so Gulab Singh named it asthe region of Jammu and Kashmir.

According to official data, about 47 thousand people have died during the conflict from last two decades in Kashmir; however Human Rights groups put the number more than one hundred thousand. At the same time, around ten thousand people went missing, thousands of women have been rapedandtortured, yet the conflict is still there; unresolved taking lives of innocent people(Dabla, 2008; Reuters, 2008).

In any conflict in the world, names of the disputed areas play an important role in depicting the nature of the conflict. Since the conflict involves more than one party, it is hard to find acceptable language in conflict resolution. Different stakeholders give different names to the conflict, which satisfies their Positions or interests. Kashmir Conflict was previously known as Indo-Pak conflict, Kashmir dispute by the different stakeholders and external community. India describes Part of Kashmir under Pakistani control as "Pakistani occupied Kashmir', while Pakistan defines part of Kashmir under Indian control as 'Indian occupied Kashmir' (Lone, 2006). On the other hand, the armed uprising and popular resistance movement changed the nature of dispute from Indo-Pak territorial conflict, to the Kashmiri self-determination movement from India. Over the years,numbers of Confidence Building Measures (CBMs) were taken by India and Pakistan, but all the initiatives fail to bring long-term peace in the region. In the meantime, Kashmiri movement went again back to its Non-violent mode since august 2008, which created the opportunity for India and Pakistan to solve this conflict, once for all.Though Pakistan has been repeatedly requesting India to resume dialogue, but India failed to tap the opportunity and solve the world's longest conflict "Kashmir" (Thaindian News, 2009).

In this paper, we would like to examine two questions: why Kashmiris chose to go for armed struggle against India? and second, why peace building initiatives lead by India and Pakistan failed to bring long term peace in the region. The study will further try to analyze the interests of the different stakeholders in order to find a peaceful, acceptable, and achievable solution to the conflict region.Therefore, the study is divided into four parts. The next section explains the genesis of conflict and the eruption of armed uprising in Kashmir. Then it discusses the peace building initiatives: conflict management andfailure of conflict resolution andthe last Section describes the initiatives towards conflict resolution.

\section{Genesis of Conflict: The Eruption of Armed Uprising}

Many people in India, Pakistan believe the armed uprising in Kashmir in 1989 was the outcome of elections rigging in 1987. However, there are proven facts since Kashmir came under Indian control elections were always rigged except 1977 and 1983 elections which were relatively considered free and fair (Bose, 2003). The argument that if election were not rigged Kashmir would not have gone for armed struggle can be simply negated by continues election riggings in Kashmir since 1953. The rise of guerrilla war in Kashmir can be attributed to many inside and outside causes, which we will try to examine in details in the next section.

\section{Kashmir: From Despotic Rule to Emancipation}

The region of Jammu and Kashmir located in the northern periphery of south Asia, surrounded by India, Pakistan, China, Afghanistan, and Tajikistan borders. According to 2001 census, the state has a population of 10,134,700 with 39,146 mi2 (101,387 km2) area. The region of Jammu and Kashmir came into existence in 1846, under the Gulab Singh and British agreement signed in Amritsar, a city in the State of Punjab in India. Before this 
treaty, the region was controlled by different dynasties on different times. On the March 15 of 1846, Gulab Singh was bestowed the Maharaja (the emblem of sovereignty) of Jammu and Kashmir. The treaty stipulated a new state by transferring the territories and the fate of people forever, in independent position to Gulab Singh and his male natural descendent.In return he agreed to pay British 0.75 million(Nanakshahi) rupees (Zutshi, 1986; Bose, 2003).After 1846 Amritsar treaty, Muslims in Kashmir were oppressed and suppressed by Sikh rulers till late 1940, they were not permitted to become officers in the government, not allowed to eat beef,

The Cow is being worshiped by some Hindus and eating beef is not allowed.

However, in Kashmir, the majority of population is Muslims and they eat beef but

the Hindu ruler imposed a rule to give death sentence to those who slaughter cow.

and were forced to work without any compensation. Those who would slaughter the cows would get death sentence, this practice continued till 1920, and the punishment was later reduced up to 10 years of imprisonment. These draconian rules manifested the Hindu rulers' barbarism against his subjects who were in majority. The harsh treatment towards these majority communities forced them to remain very poor compared to other ethnic groups like Hindus, and Sikhs (Bose, 2003). With the Indian national movement against British rule gaining strength in India, In Kashmir a school teacher sheikh Mohammad Abdullah, (who later become popular leader of Kashmir) and some of his associates organized Reading room Association in Srinagar (the summer capital of Jammu and Kashmir) in 1930s, which became birthplace of political awakening in Kashmir. In July 1931 some young Muslims went to meet Maharaja with a list of grievances they have been facing over the years. But, they end up facing the bullets of Maharajas police with the result twenty one people were killed by the police firing. This was the turning point of Kashmiris political mobilization when "dumb-driven cattle" raised the standard of revolt in 13july, 1931(Khan 2001 quoted in Boss, 2003) thus marked the beginning political consciousness of Kashmiris, a community which has been shaken, butchered, and subjugated rose against Dogra Rule.

The despotic Dogra regime started in Kashmir in 1846 and lasted till 1947. During

this time Kashmiri people were subjected to extreme brutal force of Dogra Rulers.

Henceforth did not stop to fight for liberation. The strength of the movement gave birth to a party (Muslim Conference) headed by Sheikh Mohammad Abdullah, who later did land reforms in Kashmir, which entitled all the Kashmiris with land, thus helped them to have a relatively better economic life(Bose, 2003).

\section{Kashmir: Emancipation to Colonization}

With the India and Pakistan getting independence from Britain in 14-15 August1947, British advised princely states that numbered 562 to join either India or Pakistan, based on their culture, religion and geographical proximity as they were free to join either of the two countries or remain independent after the lapse of British paramountcy over them. All the States join either India or Pakistan except three states; Hyderabad, Junagadh, and Kashmir. The ruler of the Junagadh acceded to India, and fled to Pakistan, because majority of his subjects were Hindus. However the ruler of the Hyderabad did not join any of the country, but his state was attacked by India and brought under their control in September 1948.The ruler of the Kashmir didn't also join either of the countries. From 15th August, 1947 -27 October, 1947, Kashmir remained independent, though it was not recognized by any international form. During this period a revolt broke out against Maharaja in northwestern part of Jammu (winter capital of Jammu and Kashmir State), the 
people in the region have been subjugated by the Maharaja's Army and were imposed exorbitant taxes (Schofield, 2002). This revolt later resulted the formation of Azad (independent) Kashmir, commonly known as Pakistani administered Kashmir(Boss, 2003). This incident encouraged Pakistan and they sent more tribal forcesto Kashmir, to bring whole Kashmir region under its control. Fearing the attack, the Maharaja of Kashmir, sought military support from India, to fight with Pakistani tribal forces. The Maharaja of Kashmir, and Mountbatten the then governor general of India signed an agreement that once the law and order had had been restored and the invader "Tribal forces" had expelled/eliminated the instrument of accession will be ratified according to the wishes of people (Bose, 2003). In the same year, November, 1947 Jawaharlal Nehru, India's first Prime Minister promised that the future of Kashmir will be decided according to the wishes of Kashmiri people, but India never kept its promise to hold plebiscite which she had agreed to do according to UN Security Council guidelines (Govt. of AJK).

While maintaining control on the Kashmir, India started so called election presses in the region. In the process of so called elections, one leader was enthroned and the other was dethroned to serve Indian interests. The so called leaders would remain on the seat as long as they won't question the accession of Kashmir with India (Ganguly 1996). Since 1947, India did everything to legitimize its control on Kashmir. Even when Sheikh Abdullah as a Prime Minister of Kashmir voiced for Independence, he was arrested and thrown to the jail. India appointed their puppet as the Prime Minister of Kashmir who did everything what India wanted him to do, to save his seat. In the absence of popular Kashmiri leader Sheikh, India did many constitutional changes in Kashmir, which goes from 1958, constitutional change which allowed Indian Nationals to join Kashmir civil services, to the nomenclature change in Sadr-i- Riyasat (the president of the State) to the governor of the State, and from The Prime Minister of Kashmir to the Chief Minister of Kashmir in 1965. The election was first time properly held in 1972 but Plebiscite Front (A group run by Sheikhs associates who demanded for plebiscite in Kashmir as per UN Security Council Guidelines) was banned from contesting elections (Lone, 2006; Bose, 2003).

In 1987, the pro-Kashmir leaders from Muslims United Front (henceforth MUF) decided to contest election again. The contest was between pro-Kashmiri Mohammad Yousuf Shah from MUF, and GhulamMohi-u-din Shah from National Conference (henceforth NC) who was supported by India. During the vote counting Mohammad Yousuf Shah from MUF won the election, but the election commissioner who was part of Indian machinery declared the losing candidate as winner. When Yousuf and his associates resisted and protested against the move, they were beaten up and taken to the jail. The Yousuf is now known as Salah-u-din, the head of United Jihad Counsel (UJC) (an Amalgam of Kashmiri Guerrilla groups). This was the last peaceful resort by Kashmiri people to demand for their right to self-determination through ballot. Yaseen Malik, Chairman of Jammu and Kashmir Liberation Front (JKLF), the close aid of Yousuf alias Salah-u-din, who was poling agent to Yousuf in the elections was quoted saying: "They called me a Pakistani bastard. I told them I wanted my rights, my vote was stolen, I am not pro-Pakistan but have lost faith in India"(Yaseen, quoted in Boss, 2003).

\section{The Causes of Armed Uprising}

There were a number of internal and external events which became the reason for rise of guerrilla movement in Kashmir.The internal reasons were subjugation of Kashmir people by Indian government and Indian sponsored government in Kashmir. As already mentioned India tried to curb the voice of decent at every point, and ultimately when 
MUF tried joining the election in order to fight inside the system, they were put in jail (Ganguli, 1996).However, this was not the only reason. There were a number of reasons linked to this one. Some of the main reasons for the rise of armed movement can be attributed to the following contemporary developments.

- Education

Education played an important role in political mobilization; Ganguli calls it a vital element of political mobilization in Kashmir during nineties. There was drastic increase in literacy rate in overall Kashmir region, literacy rate rose from $11.03 \%$ in 1961 to $26.67 \%$ in 1981 , which certainly helped in political conscious of people, secondly the Madrasa (Non formal schools) run by Jammat-e-Islamia (a religious organization) again played an important role in spreading message about rights, and independence etc. On theother hand a number of Palestine Students came to study in Kashmir University during 1980, who also influenced the local students in the area, by narrating the stories of Intifada in Palestine, (Ganguli, 1996).

- Electronic and Print Media

Second point is tied to the first one, which isthe Role of Electronic and print media. The media played an important role in armed uprising in Kashmir. Before the media boom there was a communication gap between Kashmir and the rest of the world, so people did not have much access to the world happenings. The Palestine intifada and the fall of Berlin wall, the Soviet withdrawal from Afghanistan and Indian Army withdrawal from Sri Lanka were some of the examples which happen during this era, and with the access to news, people got inspiration from these happening which become another reason for rise of guerrilla movement in Kashmir (Bose, 2003; Ganguli, 1996).

The other reasons are economic development, ethno religious mobilization, and above all role of Pakistani Inter-Services Intelligence (ISI) who persuaded and recruited young Kashmiri to fight against India (Ganguli, 1996). However, deep down the non-fulfillment of promises given by India forced youth to choose this ultimate resort of resistance. With the increase in economy and education, people realized the importance of life. As Huntington says economic development may lead to political instability, he further argues the modernization reduces familyties, and generates demand for political participation (Huntington quoted by Ganguli, 1996).

\section{The passage from Violence to Non-violence}

I remember, as a child in the 1950, hearing my parents talk about the value of Kashmir as a place of great beauty, half way around the globe, where world war III might begin(Strobe Tolbert, former President Brookings Institute).

Kashmir armed conflict which started in 1989, has already taken a huge death toll, and destructed thousands of houses, displaced and divided thousands of families, created mayhem everywhere. The armed movement which was earlier secular in nature, was hijacked by pro-Pak pan Islamic militants, which made the movements more bloody (Runner and Chafe, 2007).With the large scale death and destruction, the 20 years of struggle changed the discourse in the conflict, which made historical context of conflict irrelevant and transformed it into sacrificial context, "the conflict in Kashmiris a result of unfulfilled aspirations not unfulfilled grievance"(Lone, 2006).Amidst these aspirations, India's delay-delaying tactics to solve the conflict, Kashmir conflict have now again tuned into peaceful movement. People no longer want their demands to be met on the behest of gun; the beginning of this peaceful movement could be seen in August 2008 civil uprising, in which more than 3 hundred thousand people took part (Roy, 2008). The 2008 civilian 
protests were followed by 2009 and 2010 protests in which hundreds of thousands of people took part to press for their demands-freedom from India. This transition from violent to non-violent movement however did get least acknowledgment from both India and Pakistan governments. At the same time International community also failed to acknowledge this transition from violent to no-violent means of struggle which is a very important period for the conflict management. If this chance is again missed this conflict has every capacity to start another India Pakistan war in near future.

\section{Peace building Initiatives: Conflict Management, No Conflict Resolution}

The conflict management refers to the management, control to the long-term conflict, where conflict resolution does not seem to be possible in near future. So the authorities on the helm of affairs try to decrease the effects of the conflict or follow some time-buying, peacekeeping, confidence/trust building measures to limit the destruction. The problem with the "management tactics" is, it tries to find the ways to control the people like physical objects, besides it works more on reduction and control side than addressing the root problem (Lederach, 1995). The history of Kashmir since 1947 teaches us, India has been always trying to use "management" strategy to solve the conflict in Kashmir. Whether, it is using military power to crush the people of Kashmir, or applying it colonial masters (Britain's) strategy of divide and rule.

The peace building or conflict resolution process between India and Pakistan dates back to the 1948, but so far both the countries have failed to reach any final settlement on the issue. The initiatives of conflict resolution or conflict management can be divided into two phases, one from 1948 to 1989, in which it was direct negotiation between India and Pakistan, with the help of International Community. During this period India and Pakistan fought two major wars on Kashmir, thus it was confrontation between military and military. This war did not remain for longer period, so it did not had to use different methods to manage conflict, except to keep vigil on the borders , and secure its position during the negotiation, However, with the eruption of armed movement in 1989,India had to use different conflict management methods to contain the conflict, here the fight is not between two armies, but between occupier and occupied, between small guerrilla groups and 6 hundred thousand regular Indian army, between unarmed civilian and armed forces (Bose, 2003).

The first step towards resolution of Kashmir was adopted by United Nations Commission for India and Pakistan (UNCIP) in august 1948. The UNCIP was established after India lodged a complaint in January 1, 1948 to the UN Security Council against Pakistan, accusing it for launching tribal attacks in Kashmir. In the same year august 13, 1948, UNCIP passed a resolution for cease fire between the two countries, withdrawal of Pakistan troops and tribal forces followed by Indian troops, and hold plebiscite in which "future status of the state of Jammu and Kashmir will be determined in accordance with the will of people" (Dasgupta 1948 quoted in Bose, 2003).In the following year in January 1,1949 India and Pakistan signed Karachi declaration in which they abided UN established ceasefire line which gave India control of 139,000 square kilometers, and Pakistan 83807 square kilometers. This was the first agreement towards resolution between the two countries (Lone, 2006; Bose, 2003). Over the years India and Pakistani leadership hold many dialogues on the Kashmirissue, but no concrete step for the resolution of Kashmir could be seen. The first concrete agreement between the two countries was Indus water treaty, which was mediated by the World Bank in 1960. 
This treaty gives right to India and Pakistan to use water from the rivers flowing from Kashmir. However, Kashmiri people are not happy with the agreement, as they have not been given royalty of the water. Kashmiri nationalist are now demanding royalty from both the countries.

However, Kashmiri leadership was not involved in the negotiation, with the result there is increasing pressure from Kashmiri leadership to redraft the Indus-water treaty, to secure Kashmiris rights in the deal. The second agreement was signed after 1965 war, between the two countries. This agreement is called Tashkent agreement, which was signed in Tashkent a city in Uzbekistan under the USSR sponsorship in January 1966, under the agreement both the countries agreed to withdraw their forces positioned prior to August 1965 (Lone, 2006). The third agreement came into place in 1972, after India-Pakistan war in Eastern Pakistan (The present Bangladesh), this agreement between the then Prime Ministers of India and Pakistan, Mrs. Indira Gandhi, and Mr. Z.A. Bhutto is called Shimla Agreement in which both countries agreed to turn ceasefire line into Line of Control (LOC). This was the last agreement signed between India and Pakistan prior to 1989 uprising.

From 1948 to 1971, UN Security Council passed twenty three resolutions on Kashmirissue. In January 1949, the UN Military Observers Group in India and Pakistan (UNMOGIP) was established. The group is as an extension to the United Nations Commission on India and Pakistan established by Security Council Resolution 39 of 1948. However, no concrete contribution of the (UNMOGIP) office which still functions in the summer capital of the Jammu and Kashmir has been seen so far (Ahmad, 2008).From 1972, India changed its commitment of holding plebiscite in Kashmir, it now calls Kashmir as an Atoot-Ang (integral part), and on the other hand Pakistan calls it a Sheh-Reg(jugular vain), in this politics of ShehReg and Atoot-Ang people in Kashmir waited till 1989 to secure their national identity, and finally lead revolt when they did not see any hope in peaceful resistance.

The post 1989 situation turned much verse then before, almost everybody young, old, women and man joined protests against India. This period also saw rise of guerilla moment which was supported by whole Kashmir valley. As Bose (2003) rightly calls it an Intifada phase of Kashmir uprising. Thousands of unarmed and armed people were killed during this time. From January 21-23,in just three days, around three hundred unarmed protesters were killed by the Indian army(Bose, 2003). Bose divided the war in Kashmir from 1989 into three phases, one from 1990 to 1995, which he calls Intifada phase, second from 1996 to 1998demoralization and atrophy phase, and third from 1999 to 2002 Islamic radicalism or fidayeen (suicide squad) phase(Boss, 2003). However, two more phases happened after 2002, one was from 2003-2007, which we call CBM building phase; and from August 2008, onward which is revival of Intifada phase. Since 1989, India and Pakistan initiated a number of CBMs particularly since July 2003, some of the important development which happened was Ceasefire on border since November 2003, cross LOC bus in 2005 and opening of borders in five points during October 2005 earthquake which provided chance to the divided families to meet each other after 60 years (Renner and Chafe, 2007). However, none of these CBMs helped to bring any positive change towards resolution, people saw it as disaster control measures rather than efforts towards conflict resolution, and the assumption came true, in the 2008 August uprising.

The protests have now again become routine, because India fails to fulfill the aspirations of people, the mistrust is so deep even if India has bonafide intentions to take some initiatives for the solution of Kashmir, people in Kashmir see it as India new policy to buy time. This was also stated by Indian supported chief minister of Jammu and Kashmir in a press conference, where he said people have huge mistrust on the government, any effort of government is looked as with suspicion .So the question is why these initiatives fail, can 
be traced from many strategy of management against resolution. The second reason for the failure of resolution initiatives can be seen in the context of Roger Fisher and William Ury Theory "Interest based negotiation". According to them, the biggest roadblock in the conflict resolution is 'positions based bargaining', while the one side wants something which totally goes against the position of the other (Fisher et al., 1981). Over the years all the three stakeholders (Kashmir, India and Pakistan) are doing positional bargaining, though Kashmiri leadership, and Pakistani position at the time of Mushraf's rule showed much flexibility, but same could not be found from India, with the result no positive outcome was seen from one sided flexibility approach. Uri and Fisher's theory is that all the disputes have negotiable interests, behind the positions, so to address the conflict we need to understand the interests. The third problem which has been observed is selection and involvement of real representatives of Kashmir in talks. India and Pakistan invites only those Kashmiri leaders to their peace building meeting, who support their respective countries positions, with the result the real representatives of Kashmir remain unaddressed, and primarily because of the reason they won't accept the Indian or Pakistan centric solution.

The forth important thing happened, all the CBMs where credited to Indian politicians, or Indian sponsored Politicians in Kashmir, with the result there was not much ownership inside the valley (Lone, 2006). Had India initiated these CBMs through Separatists (the amalgam fighting for Kashmiri Independence) the CBMs would have lead positive impact in the valley.

\section{TOWARDS CONFLICT RESOLUTION}

Peace processes are usually studied from one (or a mix) of two perspectives: from a liberal conflict resolution perspective, where the focus is on appropriate strategies and techniques for negotiation, confidence building, third party mediation, and so on;or from a political realist perspective, where emphasis is placed on international and domestic political changes, including the impact of individual leaders, in driving peace processes (Selby, 2007). During the period of conflict in Kashmir, a number of vision documents for the solution of Kashmir were produced, which includes Self Rule proposal by ex-president of Pakistan Mr.ParvezMushraf and from the separatist and Kashmiri perspective a vision document "Achievable Nationhood" which was drafted by the Peoples Conference in Kashmir in 2005. However, No such proposal or solution was produced by India so far. Thus India sticks to its position of Atoot-Ang. The solution to this stubborn approach can be found from the above mentioned Fisher and Uri's Interest based negotiation. The key to solve the issue is to understand the interests of the key stakeholders. If the interests of the all the parties are clearly identified, and addressed this will bring out-of-box, win-win solution. To get the win-win solution India and Pakistan need to go from bilateral talks to trilateral talks and involve real Kashmir leadership in theresolution process. The absence of real representatives in any negotiation process will not bring peaceful, long lasting solution to the region

Stakeholder Analysis of Kashmir Conflict

\begin{tabular}{|c|c|c|c|c|}
\hline & Pakistan & India & Kashmir & $\begin{array}{c}\text { External Actors } \\
\text { (UN) }\end{array}$ \\
\hline Position & $\begin{array}{l}\text { - Kashmiris Jugular vain } \\
\text { - Hold plebiscite } \\
\text { - Independence of } \\
\text { Kashmiris acceptable } \\
\text { - Self-Rule }\end{array}$ & $\begin{array}{l}\text { Integral part } \\
\text { Solution can be } \\
\text { possible within the } \\
\text { borders }\end{array}$ & $\begin{array}{l}\text { - Independent Nation } \\
\text { - Regional Autonomy } \\
\text { Self-Rule can be } \\
\text { acceptable }\end{array}$ & - Plebiscite \\
\hline $\begin{array}{l}\text { Major } \\
\text { Interests }\end{array}$ & $\begin{array}{l}\text { - Complete two Nation's } \\
\text { Theory concept } \\
\text { - No threat to the }\end{array}$ & $\begin{array}{l}\text { Maintain secular } \\
\text { nature of the } \\
\text { Country }\end{array}$ & $\begin{array}{l}\text { - Control on Economic } \\
\text { affairs } \\
\text { - Religious and }\end{array}$ & Peace in the region \\
\hline
\end{tabular}

Asian Business Consortium | AJHAL 


\begin{tabular}{|c|c|c|c|c|}
\hline & $\begin{array}{l}\text { national security } \\
\text { Secure rights of } \\
\text { Kashmiri people }\end{array}$ & $\begin{array}{l}\text { No threat to } \\
\text { National security }\end{array}$ & $\begin{array}{l}\text { cultural freedom } \\
\text { - Direct contact with } \\
\text { the world } \\
\text { - Preserve Kashmiri } \\
\text { identity }\end{array}$ & \\
\hline Options & $\begin{array}{l}\text { - Kashmir becomes part } \\
\text { of Pakistan. } \\
\text { - Kashmir as an } \\
\text { independent country } \\
\text { - Regional autonomy and } \\
\text { Joint control on borders } \\
\text { - Kashmir become part of } \\
\text { India }\end{array}$ & $\begin{array}{l}\text { Kashmir part of } \\
\text { India } \\
\text { No change in } \\
\text { borders, regional } \\
\text { autonomy } \\
\text { Independent } \\
\text { Kashmir } \\
\text { Kashmir goes to } \\
\text { Pakistan }\end{array}$ & $\begin{array}{l}\text { - Kashmir as an } \\
\text { Independent nation } \\
\text { - Regional autonomy, } \\
\text { self-rule, minimal } \\
\text { control on central } \\
\text { control } \\
\text { - Join Pakistan. } \\
\text { - Join India }\end{array}$ & - ---- \\
\hline Legitimacy & \begin{tabular}{|l|} 
- Two Nation's theory \\
- Challenge to Accession \\
- UN resolutions \\
- Some support from \\
Kashmiri people
\end{tabular} & 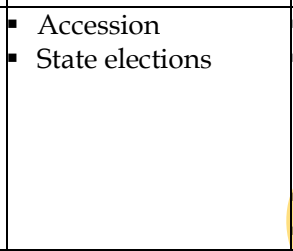 & $\begin{array}{l}\text { - Coerced accession } \\
\text { - Historically, } \\
\text { geographically, } \\
\text { ethnically, culturally } \\
\text { a different nation } \\
\text { - UN resolutions } \\
\text { - Right to freedom }\end{array}$ & $\begin{array}{l}\text { Involvement since } \\
1947,23 \text { resolutions } \\
\text { passed }\end{array}$ \\
\hline $\begin{array}{l}\text { Alternatives } \\
\text { (BANTA) }\end{array}$ & $\begin{array}{l}\text { Regional autonomy, } \\
\text { open borders, cross } \\
\text { border trade, free flow } \\
\text { of people }\end{array}$ & $\begin{array}{l}\text { Regional Autonomy } \\
\text { open borders, cross- } \\
\text { border trade }\end{array}$ & $\begin{array}{l}\text { Regional Autonomy, } \\
\text { free flow of people, trade } \\
\text { across divided Kashmir, } \\
\text { Less central control }\end{array}$ & $\begin{array}{l}\text { Regional autonomy, } \\
\text { more self-governance } \\
\text { free border, free flow } \\
\text { of people }\end{array}$ \\
\hline
\end{tabular}

The above mentioned stakeholder analysis gives us an idea about the "achievable" solutions for Kashmir. It is obvious, if the parties remain in their own positions, and looking through only one lens to attain those positions, demands, then we cannot see any solution in near future. All the parties after securing their interests need to analyze their options in order to reach their BATNA (Best Alternative to a Negotiated Agreement) to reach an agreement. After the analysis of Positions, major interests, options, legitimacy of all the stakeholders' we realized the BATNA of Kashmir conflict is around Regional Autonomy to both the sides of Kashmir. The Indian side of Kashmir can have its own Prime Minister, president while maintaining control on its most of the internal affairs. The central Indian Government can have control on the currency, external affairs and security of the region. The same strategy can be applied for Pakistan side of Kashmir. The relation between the two Kashmir's (Indian side of Kashmir and Pakistani side of Kashmir) will be free from any control. People from either of the side can go any place in the region. The relation between Pakistan and Kashmir will be visa free zone for Pakistan people, they can trade; visit the area without any official regulations. The same strategy can be applied to Indian and Pakistani side of Kashmir.

Though this solution will not be so easy to implement, but we believe this will be most viable and sustainable solution in the region, as it addresses the concerns of all the three stakeholders. Moreover, this solution is not far from the solutions proposed by Regional autonomy, Self-rule, and Achievable Nationhood documents. To find such kind of solution, we need to have visionary leadership across the board. If the leadership is visionary solutions can be found to any convoluted conflict, but if they are not, even a local dispute can become difficult to solve. As Lone puts it rightly "The dividing line between conflicts being resolvable and irresolvable is the presence or absence of statesmanship, vision and courage of the leadership to make the distinction between 'desirable and achievable'(Lone 2006). The key to reach the any solution is to first "building trust and the key to build trust is "communication", so communication should never stop. 


\section{CONCLUSION}

The conflict in Kashmir which took many forms has now become matter of prestige for both the countries India and Pakistan. The conflict which was initially considered to be territorial dispute between the two countries, have involved over the years sentiments, sacrifices of the Kashmir people. But, the fact of the matter, Kashmiri people who are the prime party in the conflict have not been involved in the resolution process. The Kashmiri movement for Independence from India went through two main stages, peaceful and violent stage from 1948 -1989, and violent stage from 1989 onwards.

During this period India used both extreme violent and non-violent methods to resolve the conflict; however both the methods failed so far. The reason for the failure of violent methods is because Kashmiri people have crossed all the stages of suppression. When people live under conflict or subjugation for long time, they get used to it. Since Kashmiris have been under direct army occupation from last 20 years, it becomes normal for them to face any smaller force, secondly, the nonviolent method, or negotiations did not yield any long term results because India does not involve real representatives of Kashmiri in talks.

Over the years many conflict resolution proposals were put forward, interestingly all the models whether from Pakistan or Kashmir find some middle ground for the solution, which can be acceptable for all the stakeholders of the conflict. Webelieve regional autonomy on both the sides of Kashmir with the free flow of people and trade across the border will satisfy the ego and interests of all the three main parties of the conflict. This solution fits under the sustainable conflict resolution/management strategies: win-win, peaceful, achievable and out-of box solutions which are core for any conflict management and Conflict resolution strategy.

\section{REFERENCES}

Ahmad, W., 2008, Kashmir and the United Nations, Counter Currents Organization. http:/ / www.countercurrents.org/ahmad270808.htm (assessed on 22-09-2012).

Bose, S., (2003). Kashmir Roots of Conflict, Paths to Peace. Vistaar Publication, New Delhi - India.

Dabla, B.A., 2008, Sociological Implications of Pandit Migration in Jammu and Kashmir, Jay Kay Book Shop Srinagar - Kashmir.

Dawn's Magazine, 2003, Books \& Authors, December 2, 2003, pp. 2.

Fisher, R., B. Patton, and W. Ury, 1981, Getting to Yes: Negotiating Agreement Without Giving In. Penguin Books, New York.

Ganguly, S., 1996, Explaining the Kashmir Insurgency: Political Mobilization and Institutional Decay, International Security,Vol. 21:2, pp. 76-107.

Govt.

of

AJK. http://www.ajk.gov.pk/site/index.php?option=com_content\&task=view\&id=2277\&Itemid=13 5 (accessed on 15 February 2012).

Hussain, M. 2009, The Economic Times,News: Politics and Nation, Omar Abdullah orders judicial inquiry into twin murders, June2, 2009.http://economictimes.indiatimes.com/News/PoliticsNation/Omar-Abdullah-ordersjudicial-enquiry-into-twin-murders/articleshow/4606504.cms (assessed on 06-11-2012).

Ilan, P., 2003, The Ethnic Cleansing of Palestine, (Oxford), Amnesty Internation Annual Report.

Lederach, J.P., 1995, Preparing for Peace: Conflict Transformation Across Cultures, Syracuse, Syracuse University Press, New York. pp. 16-17.

Lone, S.G., 2006, Achievable Nationhood, Jammu and Kashmir People's Conference, Srinagar, Kashmir.

Renner, M., and Z. Chafe, 2007, Beyond Disasters: Creating opportunities for peace, pp: 3, World watch Institute, Washington, DC, USA. 
Reuters News, 2008, India revises Kashmir death toll to 47,000, $21^{\text {st }}$ April 2008. http://in.reuters.com/article/topNews/idINIndia-36624520081121 (accessed on June 9th, 2010).

Roy, A. 2008, Land and freedom; The Guardian, August 22, 2008.http://www.guardian.co.uk/world/2008/aug/22/kashmir.india(accessed on June 9th, 2011).

Selby, J., 2007, The Political Economy of the Israeli-Palestinian and Indo-Pak Peace Processes, End of Award Report, pp:13, Department of International Relations, University of Sussex, Brighton.

Shofield, V., 2002, Kashmir: The Origin of the Dispute, BBC News. http://news.bbc.co.uk/2/hi/south_asia/1762146.stm (accessed on June 5th, 2012).

ThaindianNew, 2009, Guinness Book of World Records names Kashmir as the largest dispute in the world, May 15th, 2009. http://www.thaindian.com/newsportal/south-asia/guinness-book-ofworld-records-names-kashmir-as-the-largest-dispute-in-the-world_100192657.html (accessed onJune 3rd, 2009).

Zutshi, U.K., 1986, Emergence of Political Awakening in Kashmir, pp:20, Manohar Publications, DrayaGanj, New Delhi, India.

\section{Why Open Access ???}

"In the traditional publishing model, readers have limited access to scientific papers; authors do not have copyright for their own papers, and cannot post their papers on their own websites, which presents a significant barrier to the sharing of knowledge, as well as being unfair to authors. Open access can overcome the drawbacks of the traditional publishing model and help scholars build on the findings of their colleagues without restriction"

Submit your next manuscript at- www.abcjournals.net

ABC Journals is a unique forum to offer open access to all of its articles.

Now ABC Journal's portfolio is over nine journals, which publish both online and in print. 


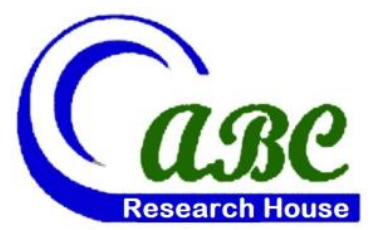

- Off Pantai Dalam, Kuala Lampur, Malaysia

- Road \# 4, Shyamoli, Dhaka-1207, Bangladesh

3900 Woodhue Place, Alexandria, VA 22309, USA

www.abcreorg.weebly.com / www.abcjournals.net

Asian Business Consortium (ABC) is a multi-disciplinary research, training, publishing, digital library supporting and service house. Though founded in 2010 as the Business and Computing organization of Asia, it was reconstituted as the ABC in 2011. It has been working for creating and nurturing talents in USA, Malaysia and Bangladesh since its inception. The objectives of consortium are solely centered round the welfare and humane attitude of the founders who enthusiastically took up this noble cause and materialized it with a view to promote research and educational activities for the encouragement of scholars to develop their knowledge, to publish their analysis oriented scientific researches in international Journals, books, the task of organizing workshops, seminars, conferences, training, personality development programs and allied services.

In addition to research activities, $\mathrm{ABC}$ provides a good number of scholarships to the poor and meritorious students at various levels of education throughout the world. It plays an important role in the field of research by funding research projects and publishing the research papers. This consortium will unquestionably become the mouth-piece of the dark horses and unacknowledged scholar whose endowed and commendable contributions shall be provided an outlet keeping in mind the greater good of the larger society of the world.

$\mathrm{ABC}$ runs the following international referred journals for creating a platform to share the thoughts of professionals, scholars and academicians throughout the world.

\section{ABC Publications (ABC Journals)}

- Asian Accounting and Auditing Advancement (4A Journal)

- Asian Business Review (ABR)

- Asian Journal of Applied Sciences and Engineering (AJASE)

- Global Disclosure of Economics and Business (GDEB)

- $\quad$ ABC Journal of Advanced Research (ABC-JAR)

- International Journal of Reciprocal Symmetry and Theoretical Physics (IJRSTP)

- American Journal of Trade and Policy (AJTP)

- Asian Journal of Humanity, Art and Literature (AJHAL)

- Malaysian Journal of Medical and Biological Research (MJMBR)

- $\quad$ Asia Pacific Journal of Energy and Environment (APJEE)

- $\quad$ Engineering International (EI)

- $\quad$ ABC Research Alert (Online)

Each journal home page provides specific information for potential authors and subscribers. Open access policy, the quick review process, rich editorial boards and quality publications have already made $A B C$ Journals unique. ABC Journals are published under the direct supervisions of renowned academicians of the world.

Collaboration in Conference: $\mathrm{ABC}$ considers high-quality conference papers for publication. Please contact us for detailed information.

Collaboration in Publishing: If you like to start writing a book, propose a new journal or advertise in $\mathrm{ABC}$ journals, please feel free to contact us. 